\title{
COMPRESSIVE STRENGTH OF SAND-LIME BRICK WALLS
}

\author{
By H. L. Whittemore and A. H. Stang
}

\section{ABSTRACT}

Eighteen sand-lime brick walls, 6 feet long by 9 feet high, and 18 wallettes about 18 inches long and 34 inches high, of the same construction were tested in compression. Lime, cement-lime, and cement mortars were used. Half of the wall specimens were 8 inches thick and half $121 / 2$ inches thick. The sandlime brick used correspond to the grade of "medium brick" according to the classification of the American Society for Testing Materials in their specification C 21-20.

The cement mortar walls were about three times, and the cement-lime mortar walls about twice as strong as the wall specimens built with lime mortar. The deformations at design stresses were one-fourteenth as great for the cement mortar walls and one-eighth as great for the cement-lime mortar walls as the deformation in the lime mortar specimens. The average stress at failure was greater for the 8 -inch walls than for the $121 / 2$-inch walls. The factor of safety based on the usual building code requirements was 2.4 for the lime mortar walls, 3.1 for the cement-lime mortar walls, and 3.6 for the cement mortar walls.

The modulus of elasticity of the single bricks and the stress-strain curve of the mortar in the wall were determined.

The stress-strain curves of the walls were not straight lines, but can be very well represented by formulas of the type $S=C d^{\mathrm{n}}$ where $n$ is less than unity.

The ultimate compressive strengths of the walls were from 60 to 80 per cent of the ultimate strength of the wallettes.

\section{CONTENTS}

Page

I. Introduction

II. Description of the specimens and of the test methods _.

1. Sand-lime brick

2. Mortar .

3. Walls................ 59

(a) Types

(b) Size

(c) Workmanship_._. 60

(d) Construction data

1. Thickness of mortar joints_....... 61

2. Rate of building

3. Mortar materials used......... 61

(e) Aging conditions......... 61

(f) Age

(g) Testing machine

(h) Method of testing

4. Wallettes..... 62 
III. The results of the tests, with discussion.

1. Brick

2. Mortar

3. Walls

(a) Deformation of walls

1. Stress-strain curve equations

2. Secant modulus of elasticity

(b) Deformation of the mortar in the wall

the walls . . . -

(c) Behavior of the walls under load................

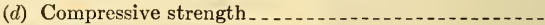

\section{INTRODUCTION}

Tests of the compressive strength of masonry walls, when different kinds of materials are used, are now in progress at the Bureau of Standards. This paper deals with the results of tests of sand-lime brick walls.

The Sand-Lime Brick Association (J. Morley Zander, president), Saginaw, Mich., cooperated in the work by furnishing the material and paying for the building of the walls. Their representative, W. H. Crume, assisted in outlining the scope of the investigation.

The bureau staff supervised the construction of the walls, made the tests, and prepared this report. Acknowledgments are especially due to C. A. Deutsch and C. T. Ervin, laboratory assistants, for aid in the inspection and tests of the specimens and computation of data.

\section{DESCRIPTION OF THE SPECIMENS AND OF THE TEST METHODS}

\section{SAND-LIME BRICK}

The sand-lime brick were obtained from a plant at Dayton, Ohio. The bricks were well mixed as they were unloaded from the cars to the laboratory floor, and it is believed that the results of the tests are free from discrepancies due to differences in the character of the brick in the various specimens. Fifty bricks were tested for absorption, 49 for tensile strength (using special spherical seated grips faced with leather), 50 for transverse strength flatwise, and 50 for compressive strength, one half of each being tested on edge and the other half flatwise. All the tests were made in accordance with the specifications of the American Society for Testing Materials C 21-20, except the tensile tests and the compressive tests flatwise, for which there are no specifications.

Stress-strain curves, in compression, were obtained on 15 other brick, tested flatwise, which is the position they occupy in the wall. 

Technologic Papers of the Bureau of Standards, Vol. 19

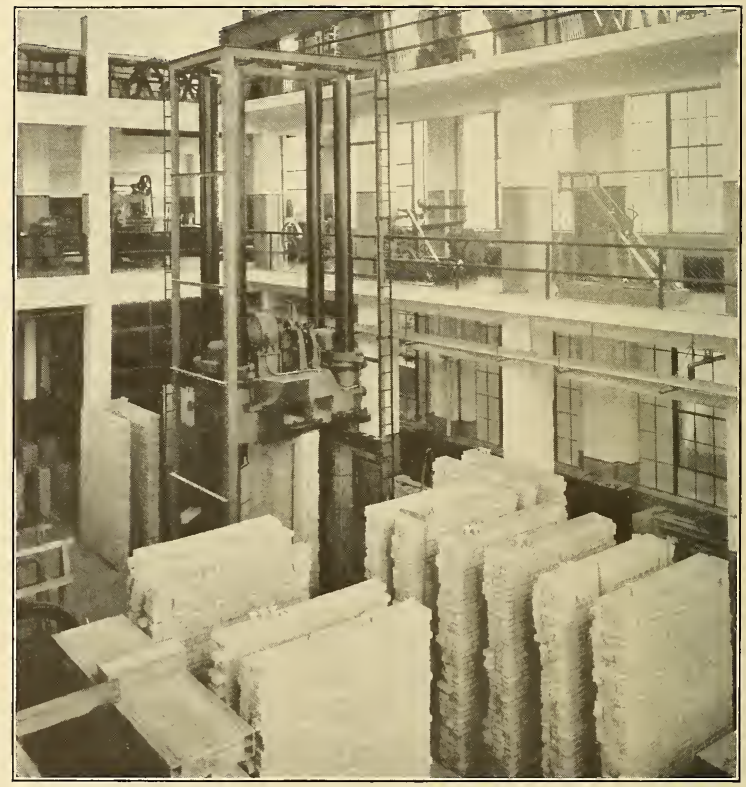

FIG. 1.-Wall specimens and testing machine 
The deformation was measured on a $11 / 2$-inch vertical gauge length at the middle of one long face. The deformations from the tests of these 15 brick were averaged and the modulus of elasticity found.

\section{MORTAR}

There were three mixtures, as follows:

Lime mortar One 50-pound bag of hydrated lime to 3 cubic feet of damp sand.

Cement-lime mortar.... One 94-pound bag of Portland cement, one 50-pound bag of hydrated lime, to 6 cubic feet damp of sand.

Cement mortar One 94-pound bag of Portland cement to 3 cubic feet of damp sand.

To obtain uniform mortar, the cement, lime, and sand were carefully weighed in the above proportions.

Since the quantity of damp sand (loose measure) varied with the moisture content, the dry weight of 3 cubic feet of sand at the first delivery was obtained and found to be 220 pounds. Each day during the construction of the walls the moisture content of a sample was obtained and the weight of damp sand necessary to make 220 pounds of dry sand computed. This value was used in proportioning the mortar for the day. Water was added to give the consistency desired by the mason and the amount of water recorded.

Three cylinders ( 2 inches diameter, 4 inches long) for compressive tests and three briquets (1 square inch in section) for tensile tests were made from the mortar of each wall. After they had been taken from the molds they were placed on the wall which they represented, as shown in Figure 1, and allowed to age under the same conditions. They were tested on the same day as the corresponding wall.

(a) TrPes-

\section{WALLS}

TABLE 1.-Wall specimens

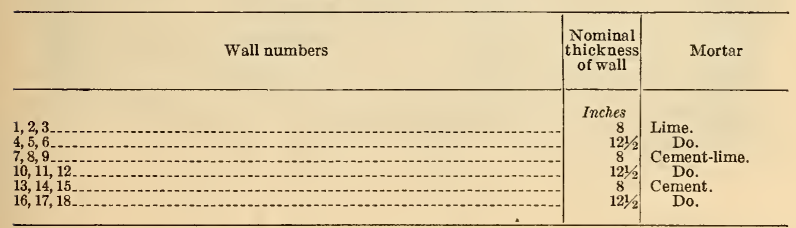

The walls were constructed with the common American bond, each sixth course being headers. In the 8-inch walls the bottom and top courses were header courses, while the $121 / 2$-inch walls had double-header courses at the top and bottom, as shown in Figure 2. 
(b) Size.-The walls were 6 feet long. When necessary, the bricks were clipped so as to project only slightly from the end of the wall, as shown in Figure 1. The height was 40 courses of brick, or about 9 feet.

(c) Workmanship.-Bids were obtained from a number of reputable local masons, and the work of building the walls was awarded to the lowest bidder. The contract specified that "no greater perfection of workmanship is to be striven for than would be the case on an ordinarily good job of brickwork." The same bricklayer built all of the walls.

The workmanship can be judged from the end view of the walls shown in Figure 2. It is evident that no attempt was made to fill the vertical joints, which are parallel to the face of the wall. The horizontal joints, however, were well filled, as is shown in Figure 3, which portrays a portion of an 8-inch cement mortar wall after bricks have fallen off during the test. Figure 4 shows a general view of the same wall from the other end. (The mark " $\mathrm{X}$ " is on the same brick in both views.) The full horizontal joints can also be seen in Figure 5, which shows a lime-mortar wall with several brick displaced.

The walls were built on steel channels, so they could be moved mto the testing machine. Starting on the level channel, the wall was kept plumb and the courses level as the work progressed. The bricks were sprinkled before laying.

(d) Construction Data.-The construction data for the walls are given in Table 2.

TABLE 2.-Construction data of sand-lime brick walls

\begin{tabular}{|c|c|c|c|c|c|c|c|c|c|c|c|}
\hline \multirow{3}{*}{$\begin{array}{c}\text { Wall } \\
\text { num- } \\
\text { ber }\end{array}$} & \multirow{3}{*}{$\begin{array}{l}\text { Nomi- } \\
\text { nal } \\
\text { thick- } \\
\text { ness }\end{array}$} & \multirow{3}{*}{ Mortar } & \multirow{3}{*}{$\begin{array}{c}\text { Aver- } \\
\text { age } \\
\text { thiek- } \\
\text { ness } \\
\text { of } \\
\text { mor- } \\
\text { tar } \\
\text { join ts }\end{array}$} & \multirow{3}{*}{$\begin{array}{c}\text { Rate } \\
\text { of } \\
\text { build- } \\
\text { ing } \\
\text { wall }\end{array}$} & \multicolumn{2}{|c|}{$\begin{array}{l}\text { Rate of lay- } \\
\text { ing bricks, } \\
\text { number- }\end{array}$} & \multicolumn{4}{|c|}{ Mortar materials used- } & \multirow{3}{*}{$\begin{array}{l}\text { Ratio } \\
\text { of wa- } \\
\text { ter to } \\
\text { total } \\
\text { dry } \\
\text { mate- } \\
\text { rial }\end{array}$} \\
\hline & & & & & \multirow{2}{*}{$\begin{array}{l}\text { Per } \\
\text { hour }\end{array}$} & \multirow{2}{*}{$\begin{array}{c}\text { Per } \\
\text { day } \\
(8 \\
\text { hours) }\end{array}$} & $\begin{array}{l}\text { Sand } \\
\text { (dry) }\end{array}$ & Lime & $\begin{array}{c}\mathrm{Ce}- \\
\text { ment }\end{array}$ & $\begin{array}{l}\text { Wa- } \\
\text { ter }\end{array}$ & \\
\hline & & & & & & & \multicolumn{4}{|c|}{$\begin{array}{l}\text { Pounds per square foot of } \\
\text { wall surface }\end{array}$} & \\
\hline & $\begin{array}{c}\text { Inches } \\
8 \\
8 \\
8\end{array}$ & $\begin{array}{l}\text { Lime } \\
0 . . . \\
\text { do }\end{array}$ & $\begin{array}{r}\text { Inch } \\
0.40 \\
.42 \\
.42\end{array}$ & $\begin{array}{r}\text { ft. } / h r . \\
11.0 \\
12.2 \\
11.7\end{array}$ & $\begin{array}{l}150 \\
160 \\
160\end{array}$ & $\begin{array}{l}1,200 \\
1,280 \\
1,280\end{array}$ & $\begin{array}{l}14.5 \\
12.5 \\
14.0\end{array}$ & $\begin{array}{l}3.3 \\
2.8 \\
3.3\end{array}$ & & $\begin{array}{l}4.4 \\
3.3 \\
4.5\end{array}$ & $\begin{array}{l}0.25 \\
.21 \\
.26\end{array}$ \\
\hline & & A verage.. & .41 & 11.6 & 160 & 1,250 & 13.5 & 3.1 & -........ & 4.1 & .24 \\
\hline & $\begin{array}{l}121 / 2 \\
121 / 2 \\
121 / 2\end{array}$ & $\begin{array}{l}\text { Lime } \\
0 \text { do }\end{array}$ & $\begin{array}{l}.44 \\
.42 \\
.42\end{array}$ & $\begin{array}{l}8.8 \\
8.9 \\
8.8\end{array}$ & $\begin{array}{l}180 \\
180 \\
180\end{array}$ & $\begin{array}{l}1,440 \\
1,440 \\
1,440\end{array}$ & $\begin{array}{l}21.5 \\
21.0 \\
23.0\end{array}$ & $\begin{array}{l}4.9 \\
4.8 \\
5.2\end{array}$ & & $\begin{array}{l}\text { 7. } 0 \\
7.2 \\
7.4\end{array}$ & $\begin{array}{l}.27 \\
.28 \\
.26\end{array}$ \\
\hline & & A verage. & .43 & 8.8 & 180 & 1,440 & 22.0 & 5.0 & -..... & 7.2 & .27 \\
\hline & $\begin{array}{l}8 \\
8 \\
8\end{array}$ & $\begin{array}{l}\text { Cement-lime } \\
\end{array}$ & $\begin{array}{l}.38 \\
.41 \\
.41\end{array}$ & $\begin{array}{l}11.3 \\
11.8 \\
10.7\end{array}$ & $\begin{array}{l}150 \\
160 \\
140\end{array}$ & $\begin{array}{l}1,200 \\
1,280 \\
1,120\end{array}$ & $\begin{array}{l}\text { 13. } 0 \\
15.5 \\
15.0\end{array}$ & $\begin{array}{l}1.5 \\
1.8 \\
1.7\end{array}$ & $\begin{array}{l}2.8 \\
3.3 \\
3.2\end{array}$ & $\begin{array}{l}4.5 \\
4.5\end{array}$ & .26 \\
\hline & & A verage... & .40 & 11.3 & 150 & 1,200 & 14.5 & 1.7 & 3.1 & 4.5 & .23 \\
\hline
\end{tabular}


Technologic Papers of the Bureau of Standards, Vol. 19

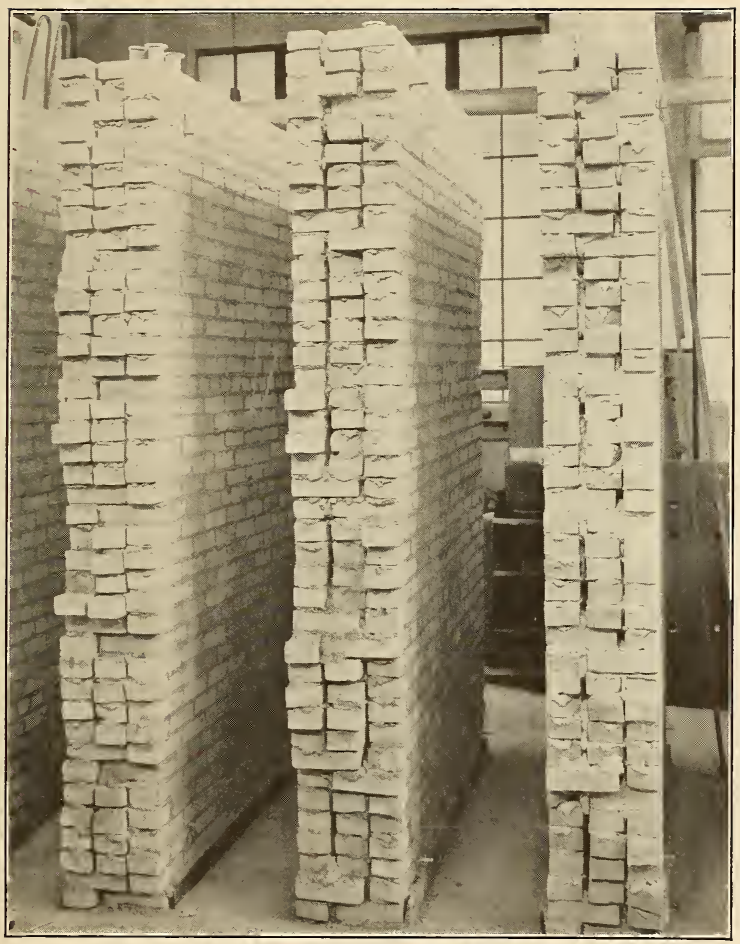

FIG. 2.-Brick walls $121 / 2$ inches thick, ccmcnt mortar 
Technologic Papers of the Bureau of Standards, Vol. 19

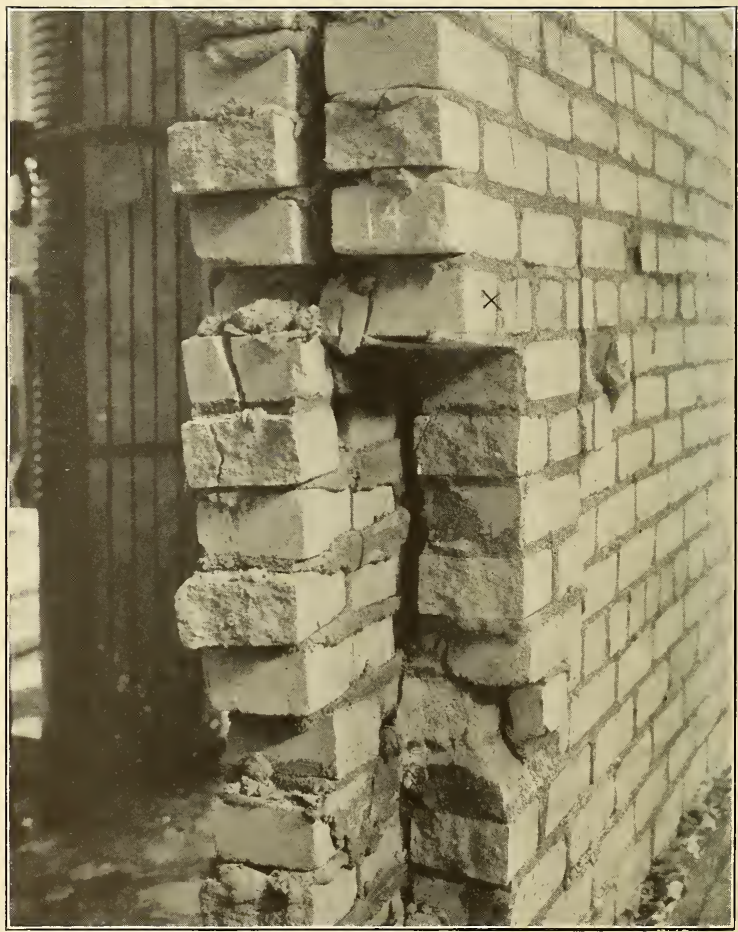

Frg. 3.-Wall No. 14 after ullimate load had been reached, 8 inches thick, cement mortar 
Technologic Papers of the Bureau of Standards, Vol, 19

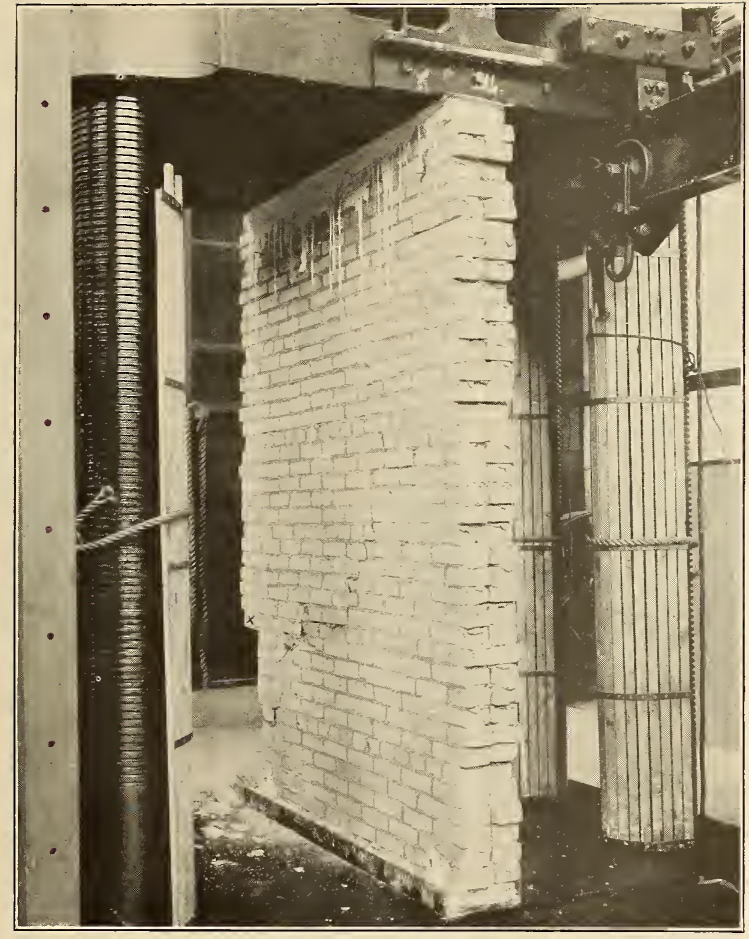

Fig. 4.-Wall No. 14 (see fig. 3) 
Technologic Papers of the Bureau of Standards, Vol. 19

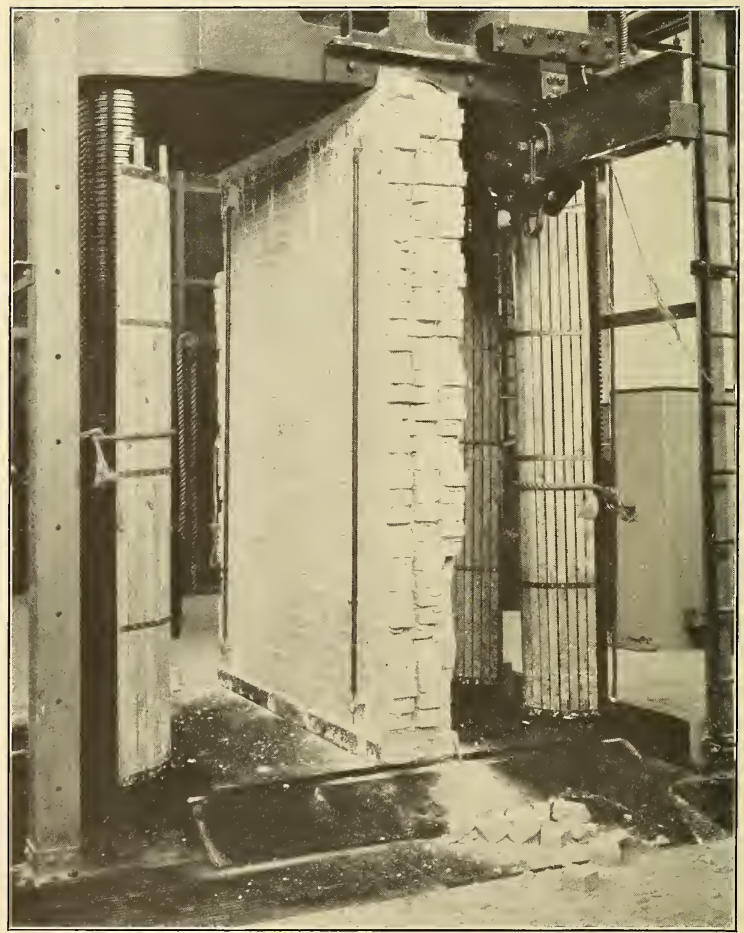

FIG. 5.-Wall No. 4 after ultimate load had been reached, $121 / 2$ inches thick, lime mortar. Note compressometers 
TABLE 2.-Construction data of sand-lime brick walls-Continued

\begin{tabular}{|c|c|c|c|c|c|c|c|c|c|c|c|}
\hline \multirow{3}{*}{$\begin{array}{l}\text { Wall } \\
\text { num- } \\
\text { ber }\end{array}$} & \multirow{3}{*}{$\begin{array}{l}\text { Nomi- } \\
\text { nal } \\
\text { thick- } \\
\text { ness }\end{array}$} & \multirow{3}{*}{ Mortar } & \multirow{3}{*}{$\begin{array}{l}\text { Aver- } \\
\text { age } \\
\text { thick- } \\
\text { ness } \\
\text { of } \\
\text { mor- } \\
\text { tar } \\
\text { joints }\end{array}$} & \multirow{3}{*}{$\begin{array}{c}\text { Rate } \\
\text { of } \\
\text { build- } \\
\text { ing } \\
\text { wall }\end{array}$} & \multicolumn{2}{|c|}{$\begin{array}{l}\text { Rate of lay- } \\
\text { ing bricks, } \\
\text { number- }\end{array}$} & \multicolumn{4}{|c|}{ Mortar materials used- } & \multirow{3}{*}{$\begin{array}{c}\text { Ratio } \\
\text { of wa- } \\
\text { ter to } \\
\text { total } \\
\text { dry } \\
\text { mate- } \\
\text { rial }\end{array}$} \\
\hline & & & & & \multirow{2}{*}{$\begin{array}{l}\text { Per } \\
\text { hour }\end{array}$} & \multirow{2}{*}{$\begin{array}{c}\text { Per } \\
\text { day } \\
(8 \\
\text { hours })\end{array}$} & $\begin{array}{l}\text { Sand } \\
\text { (dry) }\end{array}$ & Lime & $\underset{\text { ment }}{\mathrm{Ce}-}$ & $\begin{array}{l}\text { Wa- } \\
\text { ter }\end{array}$ & \\
\hline & & & & & & & Pounc & $\begin{array}{l}\text { is per } \\
\text { wall }\end{array}$ & $\begin{array}{l}\text { square } \\
\text { surface }\end{array}$ & ot of & \\
\hline \multirow[t]{2}{*}{$\begin{array}{l}10 \ldots \\
11 \ldots \\
12 \ldots\end{array}$} & \multirow[t]{2}{*}{$\begin{array}{r}\text { Inches } \\
121 / 2 \\
121 / 2 \\
121 / 2\end{array}$} & \begin{tabular}{l} 
Cement-lime.. \\
\hdashline do
\end{tabular} & $\begin{array}{r}\text { Inch } \\
0.40 \\
.41 \\
.41\end{array}$ & $\begin{array}{r}\text { Sq. } \\
\text { ft./hr. } \\
6.0 \\
8.0 \\
8.2\end{array}$ & $\begin{array}{l}120 \\
160 \\
170\end{array}$ & $\begin{array}{r}960 \\
1,280 \\
1,360\end{array}$ & $\begin{array}{l}22.5 \\
22.5 \\
23.0\end{array}$ & $\begin{array}{l}2.6 \\
2.5 \\
2.6\end{array}$ & $\begin{array}{l}4.8 \\
4.8 \\
4.9\end{array}$ & $\begin{array}{l}6.6 \\
7.2 \\
7.1\end{array}$ & $\begin{array}{l}0.22 \\
.24 \\
.23\end{array}$ \\
\hline & & A rerage. & .41 & 7.4 & 150 & 1,200 & 22.5 & 2.6 & 4.8 & 7.0 & .23 \\
\hline \multirow[t]{2}{*}{$\begin{array}{l}13 \ldots \\
14 \ldots \\
15\end{array}$} & \multirow[t]{2}{*}{$\begin{array}{l}8 \\
8 \\
8\end{array}$} & Cement & $\begin{array}{l}.44 \\
.43 \\
.43\end{array}$ & $\begin{array}{l}11.6 \\
10.8 \\
10.8\end{array}$ & $\begin{array}{l}150 \\
140 \\
150\end{array}$ & $\begin{array}{l}1,200 \\
1,120 \\
1,200\end{array}$ & $\begin{array}{l}13.5 \\
15.0 \\
18.5\end{array}$ & & $\begin{array}{l}5.9 \\
6.3 \\
7.8\end{array}$ & $\begin{array}{l}4.1 \\
4.9 \\
5.0\end{array}$ & $\begin{array}{l}.21 \\
.23 \\
.20\end{array}$ \\
\hline & & A verage. & .43 & 11.1 & 150 & 1,170 & 15. 5 & - & 6.7 & 4.7 & .21 \\
\hline \multirow[t]{2}{*}{$\begin{array}{l}16 \ldots \\
17-\ldots \\
18 \\
\end{array}$} & \multirow[t]{2}{*}{$\begin{array}{l}121 / 2 \\
121 / 2 \\
121 / 2\end{array}$} & $\begin{array}{l}\text { Cement } \\
\text { do }\end{array}$ & $\begin{array}{l}.47 \\
.44 \\
.43\end{array}$ & $\begin{array}{l}8.9 \\
9.2 \\
8.7\end{array}$ & $\begin{array}{l}170 \\
180 \\
180\end{array}$ & $\begin{array}{l}1,360 \\
1,440 \\
1,440\end{array}$ & $\begin{array}{l}23.0 \\
22.5 \\
20.0\end{array}$ & & $\begin{array}{l}9.9 \\
9.5 \\
8.6\end{array}$ & $\begin{array}{l}6.9 \\
5.4 \\
6.0\end{array}$ & $\begin{array}{l}.21 \\
.17 \\
.21\end{array}$ \\
\hline & & Average.. & .45 & 8.9 & 180 & 1,410 & 22.0 & & 9.3 & 6.1 & .20 \\
\hline
\end{tabular}

1. Thickness of mortar joints.-The average thickness of mortar joints was practically the same for all the walls. The results indicate that the impression that, with ordinary workmanship, cementmortar joints can not be made as thin as lime-mortar joints does not appear to be justified.

2. Rate of building. - The mason's time was recorded for each wall, beginning when the base plate was level and ending when the last brick was laid. The time, about 10 minutes, required for erection of the scaffold was included.

The rate at which the walls were built and therefore the labor cost was practically the same for all walls of the same thickness. Table 2 shows that the rate was not affected by the mortar used, as the cement mortar walls were built as rapidly as those for which lime mortar was used. As wall No. 10 was the first, the rate was naturally slower than for the other walls.

3. Mortar materials used.-Table 2 shows the amounts of the various mortar materials used for each square foot of wall surface. As the plasticity of the mortar, and probably its strength, depend on the amount of water used, it is reported.

(e) Agrng Conditions.- The walls remained in the testing laboratory until they were tested. They were not sprinkled during that time.

(f) AGE.-The walls were tested from 59 to 61 days after construction. 
(g) Testing Machine.-The walls were tested in a vertical hydraulic compression machine ${ }^{1}$ having a capacity of $10,000,000$ pounds. A spherical bearing is part of the lower platen of this machine.

(h) Method of Testing.- The walls were tested in compression under central loading with freshly mixed plaster of Paris between the wall and the heads of the testing machine. The plaster was allowed to set over night before proceeding with the test. Vertical compressometers were attached near each corner as shown in Figure 5. The gauge length was about 100 inches, and the dial micrometers were read to the nearest one-thousandth of an inch at each 50 lbs./in. ${ }^{2}$ increment of load.

\section{WALLETTES}

Since the cost of the wall specimens described above is considerable, it was desired to determine whether a smaller wall than the 6 by 9 foot specimen possessed a compressive strength which had a definite relation to that of the wall specimen. These small walls are called wallettes. The wallettes were 13 courses high (34 inches) and four headers long (18 inches). Eighteen wallettes were built and, except in size, duplicated the corresponding walls. They were built by the same mason and aged under the same conditions and for the same time as the walls. That the workmanship of the wallettes is the same as that of the walls is shown in Figures 6 and 7 , in which the voids in the vertical joints and the well-filled horizontal joints of the wallettes are clearly seen. They were tested in a 600,000 -pound capacity universal testing machine using a spherical bearing.

\section{THE RESULTS OF THE TESTS, WITH DISCUSSION}

\section{BRICK}

The results of the tests of single brick are given in Table 3.

TABLE 3.-Physical properties of the sand-lime brick

\begin{tabular}{|c|c|c|c|c|}
\hline Test & $\begin{array}{l}\text { Number of } \\
\text { specimens }\end{array}$ & Maximum & Minimum & Average \\
\hline Absorption & \multirow{4}{*}{$\begin{array}{l}50 \\
50 \\
49 \\
50 \\
50\end{array}$} & Per cent & Per cent 7.7 & Per cent 13.2 \\
\hline $\begin{array}{l}\text { Modulus of rupture, flatwise } \\
\text { Tensile strength }\end{array}$ & & $\begin{array}{r}\text { Lbs./in.2 } \\
840 \\
300\end{array}$ & $\begin{array}{r}\text { Lbs./in.2 } \\
350 \\
100\end{array}$ & $\begin{array}{r}\text { Lbs. } / \text { in. } .^{2} \\
560 \\
210\end{array}$ \\
\hline $\begin{array}{l}\text { Compressive strength, llatwise (half bricks) } \\
\text { Compressive strength, edgewise (half bricks) }\end{array}$ & & $\begin{array}{r}6,220 \\
3,930 \\
\end{array}$ & $\begin{array}{l}2,700 \\
1,660 \\
\end{array}$ & $\begin{array}{l}4,150 \\
2,760 \\
\end{array}$ \\
\hline Modulus of elasticity & & \multicolumn{3}{|c|}{$1,590,000$} \\
\hline
\end{tabular}

The properties of the brick varied, as shown in Figure 8. These brick met the requircments for medium brick, American Society for Testing Materials Specification C 21-20.

1 For a description of this machine see B. S. Tech. Paper No. 101, Tests of Large Bridge Columns, by Griffith and Bragg. 


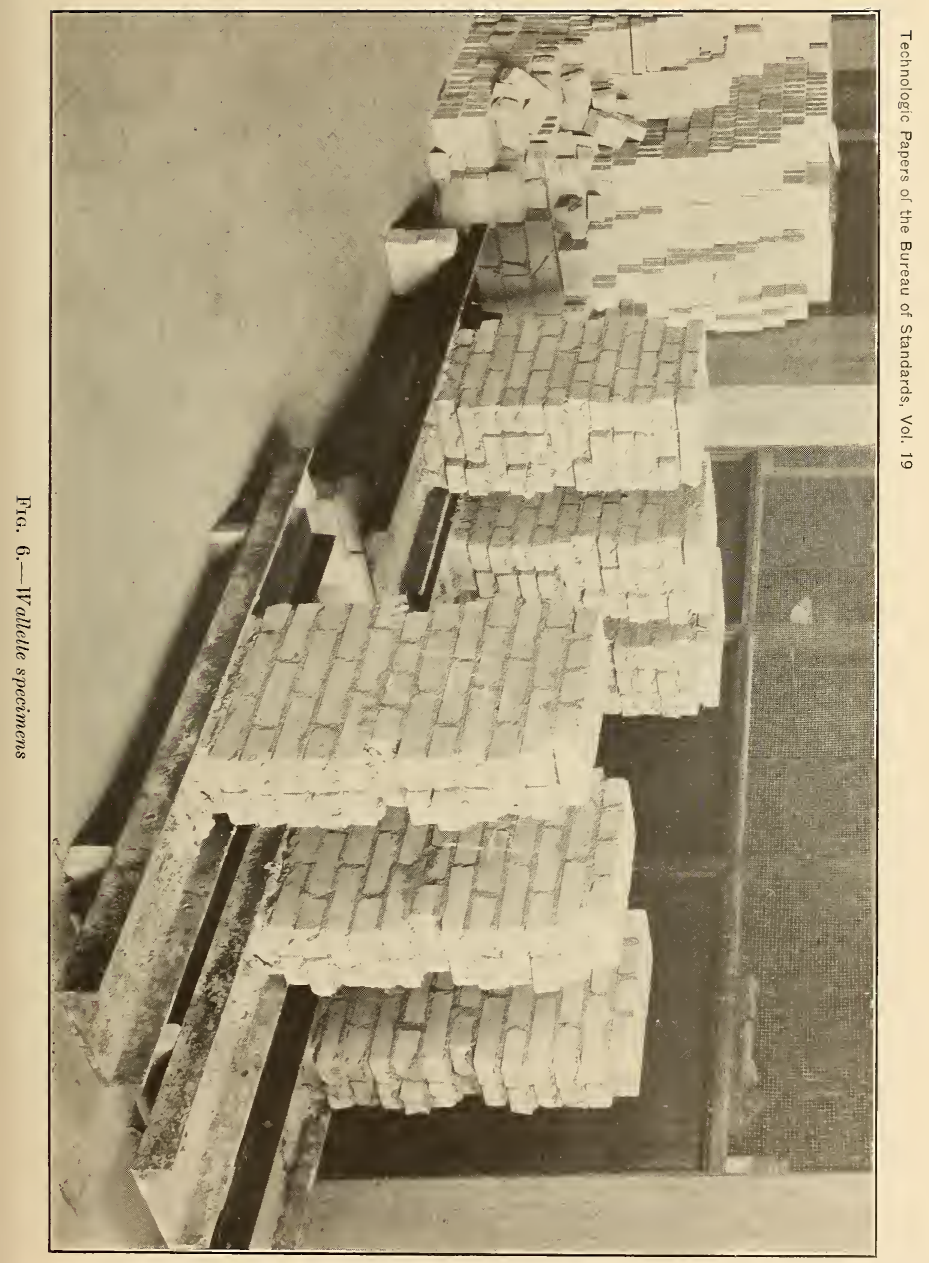


Technologic Papers of the Bureau of Standards, Vol. 19

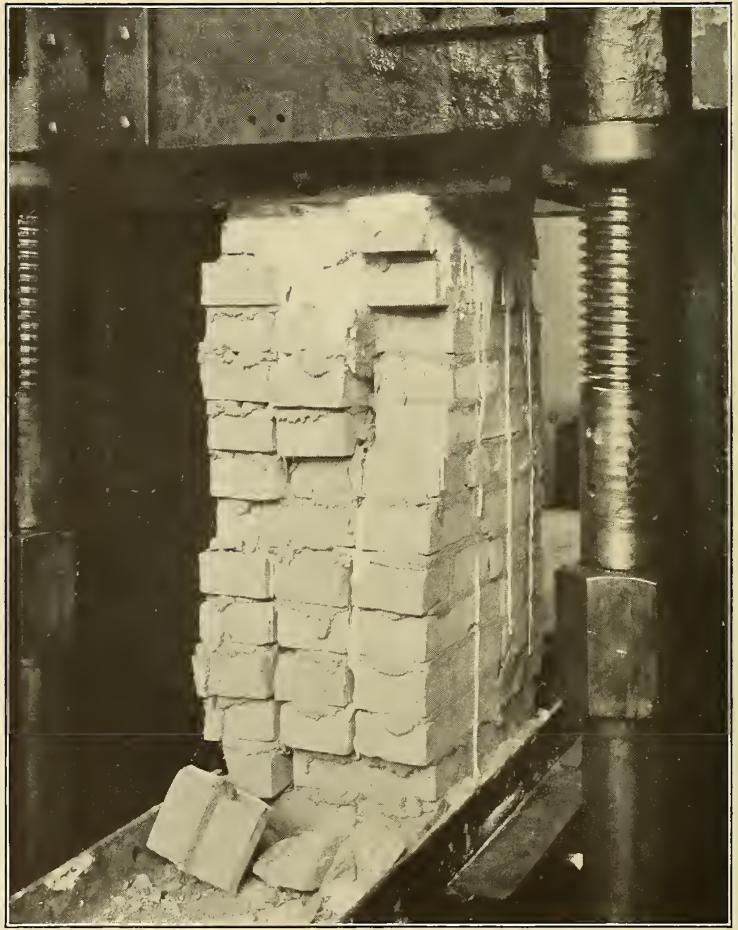

FIG. 7.-Wallette No. 18 in testing machine after ultimate load had been reached; $121 / 2$ inches thick, cement mortar 


\section{MORTAR}

The average results of the tests on the mortar specimens are given in Table 4.
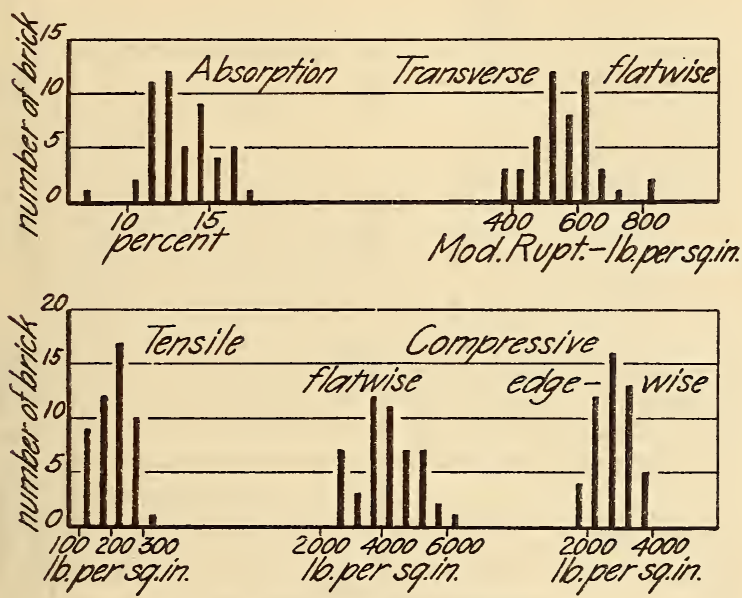

Frg. 8.-Results of tests of single bricks

TABLE 4.-Strength of mortar specimens

\begin{tabular}{|c|c|c|c|}
\hline $\begin{array}{l}\text { Nominal wall } \\
\text { thickness in } \\
\text { inches }\end{array}$ & Mortar & $\begin{array}{l}\text { Compres- } \\
\text { sive } \\
\text { strength }\end{array}$ & $\begin{array}{l}\text { Tensile } \\
\text { strength }\end{array}$ \\
\hline & Lime... & Lbs./in. ${ }_{140}^{2}$ & Lbs./in. ${ }^{2}$ \\
\hline $121 / 2$. & do & 120 & 6 \\
\hline $121 / 2 \ldots$ & Cement-fime..... & $\begin{array}{r}860 \\
720\end{array}$ & 110 \\
\hline $8-2$ & Cement & 2,120 & 200 \\
\hline $121 / 2 \ldots \ldots$ & do & 2,050 & 175 \\
\hline
\end{tabular}

These results indicate that the mortar was as uniform in strength as could be expected.

\section{WALLS}

(a) Deformation of Walls.-1. Stress-strain curve equations.In Figure 9 are plotted the stress-strain diagrams for each wall. A curve has been drawn through the average strain values for each group of walls. This curve is in no part a straight line, and, hence, the walls have no definite value for Young's modulus of elasticity.

$18363^{\circ}-25+-2$ 


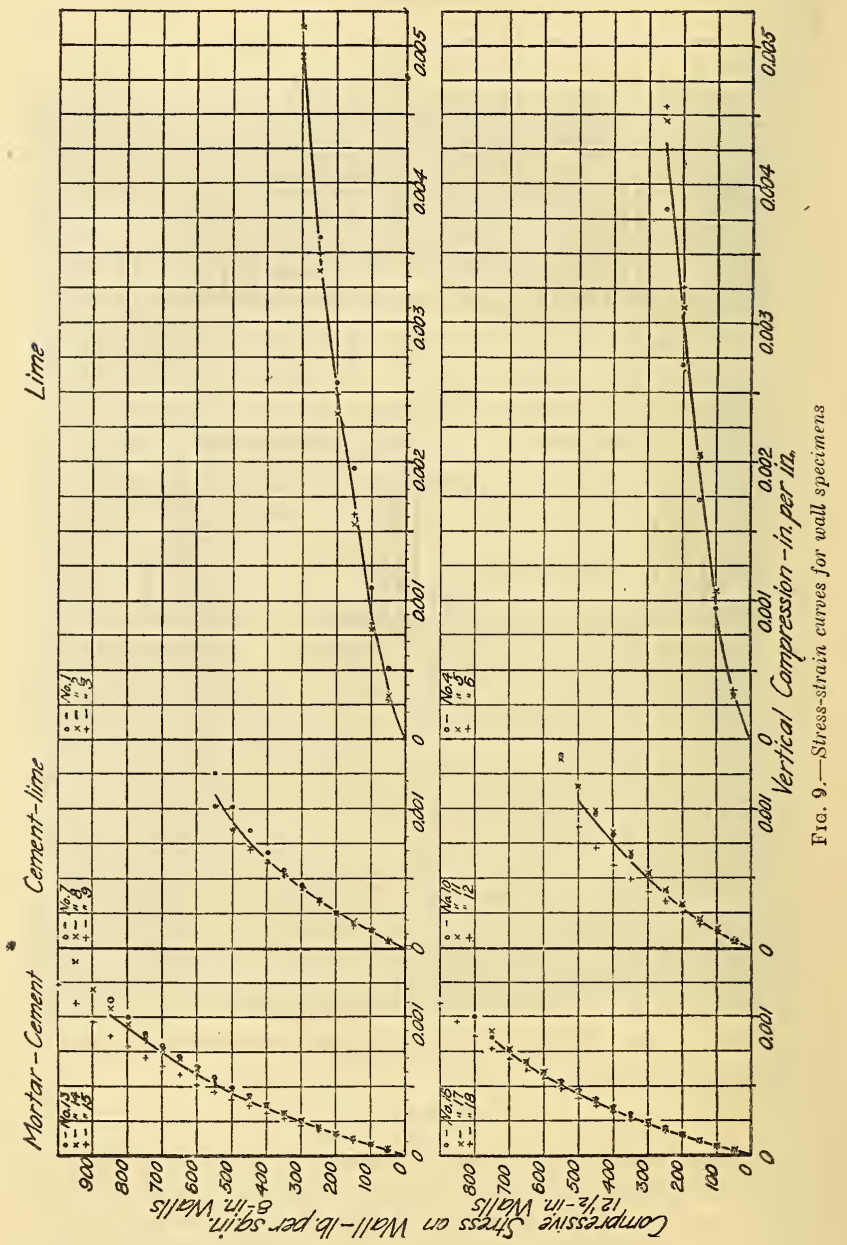


The arerage stress-strain curves are closely represented by an exponential equation of the type

$$
S=C d^{n}
$$

where

$S=$ stress, pound per square inch.

$d=$ deformation, inch per inch.

and

$C$ and $n$ are constants.

The equations are:

For 8-inch lime mortar walls . . ................ $S=11,400 \times d^{0.63}$

For $121 / 2$-inch lime mortar walls ............. $S=8,200 \times d^{0.64}$

For 8-inch cement-lime mortar walls . . . . . ...... $S=99,000 \times d^{0.75}$

For $121 / 2$-inch cement-lime mortar walls . . . ...... $S=76,600 \times d^{0.73}$

For 8-inch cement mortar walls ... _.......... $S=565,000 \times d^{0.91}$

For $121 / 2$-inch cement mortar walls_............. $S=253,000 \times d^{0.81}$

The equations for the lime mortar and for the cement-lime mortar walls give correct values up to the ultimate strength. The equations for the cement mortar walls hold only to a stress of $500 \mathrm{lbs} . / \mathrm{in}^{2}$, which is, however, well beyond the design stress. As the load on these latter walls is increased the deformations increase more rapidly than the equation indicates.

2. Secant modulus of elasticity.-Although there is no linear relation between the stress and strain in these walls, the secant modulus of elasticity, obtained by dividing the stress by the corresponding value of the strain, may be of use. These values are given in Table 5.

TABLE 5.-Results of compressive tests of sand-lime brick walls

[Walls 6 feet long, 9 feet high]

\begin{tabular}{|c|c|c|c|c|c|c|c|c|c|c|}
\hline \multirow{2}{*}{$\begin{array}{l}\text { Wall } \\
\text { No. }\end{array}$} & \multirow{2}{*}{$\begin{array}{l}\text { Thick- } \\
\text { ness }\end{array}$} & \multirow{2}{*}{ Mortar } & \multirow{2}{*}{$\begin{array}{l}\text { Secant } \\
\text { modulus of } \\
\text { elasticity }\end{array}$} & \multirow{2}{*}{$\begin{array}{l}\text { Stress } \\
\text { range for } \\
\text { secant } \\
\text { modulus }\end{array}$} & \multicolumn{3}{|c|}{ At first crack } & \multicolumn{3}{|c|}{ At failure } \\
\hline & & & & & \multicolumn{2}{|c|}{ Load } & Stress & \multicolumn{2}{|c|}{ Load } & Stress \\
\hline & $\begin{array}{r}\text { Inches } \\
8.35 \\
8.40 \\
8.40\end{array}$ & Lime & $\begin{array}{r}\text { Lbs./in. } .^{2} \\
78,000 \\
108,000 \\
111,000\end{array}$ & $\begin{array}{c}\text { Lbs./in. }{ }^{2} \\
0-125 \\
0-125 \\
0-125\end{array}$ & $\begin{array}{l}\text { Pounds } \\
150,500 \\
120,800 \\
121,100\end{array}$ & $\begin{array}{r}\text { Tons per } \\
\text { lin.ft.1 } \\
12.5 \\
10.1 \\
10.1\end{array}$ & $\begin{array}{c}\text { Lbs./ } \\
\text { in. }{ }^{2} \\
250 \\
200 \\
200\end{array}$ & $\begin{array}{l}\text { Pounds } \\
187,000 \\
190,000 \\
193,300\end{array}$ & $\begin{array}{c}\text { Tons } \\
\text { per lin. } \\
\text { ft.1 } \\
15.6 \\
15.8 \\
16.1\end{array}$ & $\begin{array}{l}\text { Lbs./ } \\
\text { in }{ }^{3} \\
310 \\
310 \\
320\end{array}$ \\
\hline & & Average. & 99,000 & n. & 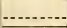 & 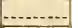 & $\ldots$ & & -......... & 315 \\
\hline & $\begin{array}{l}\text { 13. } 10 \\
13.20 \\
13.20\end{array}$ & $\begin{array}{c}\text { Lime } \\
\text { L...... do }\end{array}$ & $\begin{array}{l}96,000 \\
83,000 \\
83,000\end{array}$ & $\begin{array}{l}0-125 \\
0-125 \\
0-125\end{array}$ & $\begin{array}{l}188,600 \\
189,900 \\
189,800\end{array}$ & $\begin{array}{l}15.7 \\
15.8 \\
15.9\end{array}$ & $\begin{array}{l}200 \\
200 \\
200\end{array}$ & $\begin{array}{l}295,900 \\
262,800 \\
275,300\end{array}$ & $\begin{array}{l}24.6 \\
21.9 \\
22.9\end{array}$ & $\begin{array}{l}300 \\
280 \\
290\end{array}$ \\
\hline & & A verage. & 87,000 & & & & & & (n) & 290 \\
\hline & $\begin{array}{l}8.30 \\
8.30 \\
8.25\end{array}$ & $\begin{array}{c}\text { Cement-lime._ } \\
\ldots \text { do }\end{array}$ & $\begin{array}{l}769,000 \\
800,000 \\
810,000\end{array}$ & $\begin{array}{l}0-200 \\
0-200 \\
0-200\end{array}$ & $\begin{array}{l}239,900 \\
328,700 \\
296,300\end{array}$ & $\begin{array}{l}20.0 \\
27.4 \\
24.7\end{array}$ & $\begin{array}{l}400 \\
550 \\
500\end{array}$ & $\begin{array}{l}342,000 \\
418,300 \\
457,000\end{array}$ & $\begin{array}{l}28.5 \\
34.8 \\
38.1\end{array}$ & $\begin{array}{l}570 \\
700 \\
770\end{array}$ \\
\hline & & Average. & 793,000 & & & & & & & 680 \\
\hline
\end{tabular}

11 ton $=2,000$ pounds 
TABLE 5.-Results of compressive tests of sand-lime brick walls-Continued

\begin{tabular}{|c|c|c|c|c|c|c|c|c|c|c|}
\hline \multirow{2}{*}{$\begin{array}{l}\text { Wall } \\
\text { No. }\end{array}$} & \multirow{2}{*}{$\begin{array}{l}\text { Thick- } \\
\text { ness }\end{array}$} & \multirow{2}{*}{ Mortar } & \multirow{2}{*}{$\begin{array}{l}\text { Secant } \\
\text { modulus of } \\
\text { elasticity }\end{array}$} & \multirow{2}{*}{$\begin{array}{l}\text { Stress } \\
\text { range for } \\
\text { secant } \\
\text { modulus }\end{array}$} & \multicolumn{3}{|c|}{ At first crack } & \multicolumn{3}{|c|}{ At failure } \\
\hline & & & & & \multicolumn{2}{|c|}{ Load } & \multirow{2}{*}{$\begin{array}{c}\text { Stress } \\
\\
\\
\text { Lbs./ } \\
\text { in.2 } \\
550 \\
550\end{array}$} & \multicolumn{2}{|c|}{ Load } & \multirow{2}{*}{$\begin{array}{l}\text { Stress } \\
\\
\begin{array}{l}\text { Lbs./ } \\
\text { in. }{ }^{2} \\
570 \\
580 \\
550\end{array}\end{array}$} \\
\hline \multirow[t]{2}{*}{$\begin{array}{l}10 \ldots \\
11 \ldots . . . \\
12 \ldots\end{array}$} & \multirow[t]{2}{*}{$\begin{array}{r}\text { Inches } \\
13.05 \\
13.00 \\
13.05\end{array}$} & $\begin{array}{c}\text { Cement-lime } \\
\text { do }\end{array}$ & $\begin{array}{r}\text { Lbs./in.2 } \\
641,000 \\
639,000 \\
800,000\end{array}$ & $\begin{array}{c}\text { Lbs./in. } .^{2} \\
0-200 \\
0-200 \\
0-200\end{array}$ & $\begin{array}{l}\text { Pounds } \\
516,800 \\
513,700\end{array}$ & $\begin{array}{r}\text { Tons per } \\
\text { lin.ft.1 } \\
43.1 \\
42.8 \\
\end{array}$ & & $\begin{array}{l}\text { Pounds } \\
535,500 \\
537,500 \\
513,500\end{array}$ & $\begin{array}{c}\text { Tons } \\
\text { per lin. } \\
\text { ft. } .^{1} \\
44.6 \\
44.8 \\
42.8\end{array}$ & \\
\hline & & Average. & 693,000 & & 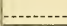 & 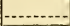 & 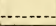 & & & 565 \\
\hline $\begin{array}{l}13 \ldots \\
14 \ldots \\
15 \ldots\end{array}$ & $\begin{array}{l}8.40 \\
8.35 \\
8.35\end{array}$ & $\begin{array}{l}\text { Cement..... } \\
\text { do }\end{array}$ & $\begin{array}{l}1,162,000 \\
1,175,000 \\
1,374,000\end{array}$ & $\begin{array}{l}0-250 \\
0-250 \\
0-250\end{array}$ & $\begin{array}{l}485,000 \\
329,900 \\
481,500\end{array}$ & $\begin{array}{l}40.4 \\
27.5 \\
40.1\end{array}$ & $\begin{array}{l}800 \\
550 \\
800\end{array}$ & $\begin{array}{l}534,800 \\
576,400 \\
622,600\end{array}$ & $\begin{array}{l}44.5 \\
48.0 \\
51.9\end{array}$ & $\begin{array}{r}880 \\
960 \\
1,030\end{array}$ \\
\hline \multirow{3}{*}{$\begin{array}{l}16 \ldots \\
17 \ldots \ldots \\
18 \ldots \ldots\end{array}$} & \multirow{3}{*}{$\begin{array}{l}13.05 \\
12.75 \\
12.80\end{array}$} & A verage & $1,237,000$ & & 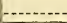 & . & & $\ldots$ & & 960 \\
\hline & & $\begin{array}{l}\text { Cement } \\
\ldots \text { do } \\
\ldots\end{array}$ & $\begin{array}{l}1,231,000 \\
1,412,000 \\
1,445,000\end{array}$ & $\begin{array}{l}0-250 \\
0-250 \\
0-250\end{array}$ & $\begin{array}{l}705,200 \\
597,200 \\
598,100\end{array}$ & $\begin{array}{l}58.7 \\
49.7 \\
49.8\end{array}$ & $\begin{array}{l}750 \\
650 \\
650\end{array}$ & $\begin{array}{l}752,300 \\
735,000 \\
869,000\end{array}$ & $\begin{array}{l}62.7 \\
61.2 \\
72.4\end{array}$ & $\begin{array}{l}800 \\
800 \\
940\end{array}$ \\
\hline & & A verage & $1,363,000$ & & & & & & & 850 \\
\hline
\end{tabular}

11 ton $=2,000$ pounds.

The stress range for which this modulus was computed is from zero to the recommended values for medium-grade brick given in the tentative report, Masonry Wall Construction, 1923, of the Building Code Committee of the Department of Commerce, which are:

$125 \mathrm{lb} . / \mathrm{in} .^{2}$ for lime mortar;

$200 \mathrm{lbs}$./in..$^{2}$ for cement-lime mortar, and

$250 \mathrm{lbs}$./in. ${ }^{2}$ for cement mortar.

A comparison of these secant moduli shows that the cementlime mortar walls were about eight times as stiff as the lime mortar walls and that the cement mortar walls were about fourteen times as stiff.

3. Permanent set.-Measurements were made of the permanent set on four walls. The partial stress-strain curres are given in Figure 10. For the cement-lime and cement-mortar walls the load was increased until the stress amounted to $400 \mathrm{lbs} . / \mathrm{in} .{ }^{2}$, then backed off until it had decreased to $50 \mathrm{lbs}$./in. ${ }^{2}$ The load before back off for the wall with lime mortar was $150 \mathrm{lbs} . / \mathrm{in} .^{2}$ In no case had there been any signs of failure before the load was decreased. It is seen from the values of the ratios of set deformation $(O A)$ to the deformation $(O B)$, as given in Figure 10, that the walls of cement mortar have about half the relative set of the cement-lime mortar walls. The set of the lime mortar wall is about three-fourths of the total deformation.

As the load was again increased the deformations at loads of 400 or 150 pounds, as the case might be, were practically the same as the deformations on the first application of these loads. 
The modulus of elasticity computed from these stress-strain curves for the second loading are given in Table 6 .

TABLE 6.-Modulus of elasticity of walls for second loading

\begin{tabular}{|c|c|c|c|}
\hline Wall number & $\begin{array}{c}\text { Thickness } \\
\text { of wall }\end{array}$ & Mortar & $\begin{array}{l}\text { Modulus of } \\
\text { elasticity }\end{array}$ \\
\hline $14-14$ & $\begin{array}{r}\text { Inches } \\
8 \\
8 \\
8 \\
121 / 2\end{array}$ & $\begin{array}{l}\text { Lime_. } \\
\text { Cement lime_-_ent } \\
\text { Cement_. }\end{array}$ & $\begin{array}{r}\text { Lbs./in. }{ }^{3} \\
\quad 450,000 \\
1,050,000 \\
1,350,000 \\
1,420,000\end{array}$ \\
\hline
\end{tabular}

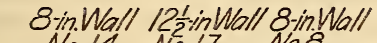

No.14 No.17 No.8

Mortar-Cement Cement Cement-lime

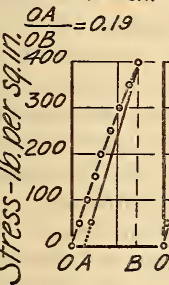

0.14

0.38 8-in. Wall
No.2

Lime

0.78

FIg. 10.-Stress-strain curves showing the permanent set in four walls

(b) Deformation of the Mortar in the Walls.- Since the deformation of the walls, made up of alternate layers of brick and mortar, is given by the equations above, and the modulus of elasticity of the brick $\left(1,590,000 \mathrm{lbs}\right.$./in..$\left.^{2}\right)$ is known, it is possible to compute the deformation in the mortar itself by taking account of the average thickness of the brick (2.26 inches) and the arerage thickness of the mortar joints as given in Table 2. These computations have been made for the 8 -inch walls, and the results are represented by the following formulas:

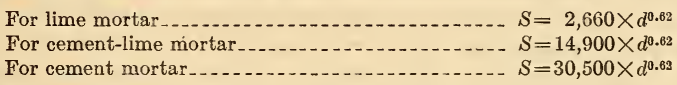
where

and

$$
S=\text { stress, pound per square inch }
$$

$$
d=\text { deformation, inch per inch }
$$

The values are doubtless dependent upon the kind of brick used and the average thickness of the mortar joints. It may be noted 
that the coefficients in the formulas are roughly proportional to the strength of the mortar, either in tension or compression, as given above.

(c) Behavior of the WALLS under Load.-During the tests of these walls failure was not accompanied by noises. It was necessary to watch carefully for visible signs of failure, and obviously it was impossible to note any failure which did not take place on the faces or ends of the wall specimens.

The values for the load when the first crack occurred, given in Table 5, are the loads at which failure of some of the brick was observed. There seems to be no relation between these loads and the maximum loads that the walls withstood. It is seen, however, that in no case was there a sign of failure until a load had been reached which was much larger than any design stress now allowed.

The first sign of failure, in all cases, for cement-lime and cement mortar walls was the breaking of one or more headers. It seems probable that this was caused by bending stresses. In each of the lime mortar walls it was noted that stretchers as well as headers were broken by the load at first crack. A consideration of the method used in building brick walls would lead one to expect initial failure in this manner. After a header course has been laid the face web is built five courses high, and it is a comparatively simple matter to keep the course level and the mortar of uniform thickness. The five courses in the back web are then laid and brought to practically the same height as the face web. The header course binding the webs together is then laid, but it is reasonable to suppose that the bedding across the webs is not as uniform as in either web. The headers, then, are more apt to break by cross bending than the stretchers in their more uniform bed. In lime mortar, however, the effect of uneven bedding is exaggerated, due to the low modulus of elasticity of this mortar, and the chances are about as great that a stretcher will rupture as a header.

As the test progressed more headers broke until in some walls all visible headers were broken when the maximum load was reached. This was particularly true of the lime-mortar walls, as shown in Figure 5. The stretcher cracks opened up and frequently extended from the top to the bottom of the wall specimen on both sides.

In all the walls some bricks were crushed by the time the maximum load was reached. The number of brick crushed was greatest in the cement mortar walls and least in those laid in lime mortar.

The loading was not continued after a marked decrease in the load showed that the maximum had been attained.

(d) Compressive Strength.-Table 5 gives the results of the compressive tests of the walls. The thickness of each wall was meas- 
ured and the loads calculated, using the measured not the nominal thickness. The stress at failure for the wall specimens of any given type are as uniform as can be expected from masonry structures built under ordinary conditions. The average results show that, for any mortar, the 8 -inch walls were stronger than the $121 / 2$-inch walls. The strength of columns is usually greater for those having a low slenderness ratio. The slenderness ratio for the 8-inch walls was about 47 and was about 30 for the $12 \frac{1}{2}$-inch walls. If the 8 -inch walls behaved like long columns under load, the ultimate strength should be less than for the $121 / 2$-inch walls. As this is not true, the greater strength of the thinner walls is probably due to the headers which tie the webs of the wall together more effectively than the headers in the thicker walls.

The strength of the walls depends greatly upon the composition of the mortar.

On the average, when 60 days old, the cement-lime mortar walls were 106 per cent stronger and the cement mortar walls were 199 per cent stronger than those built with lime mortar. Using the recommended values for brick masonry previously given, the average factors of safety obtained for these walls are:

2.4 for the lime mortar walls.

3.1 for the cement-lime mortar walls.

3.6 for the cement mortar walls.

It may be noted that in any group the wall having the lowest modulus also had the lowest strength in five of the six groups, while the wall with highest strength had the highest modulus in five of the groups.

\section{WALLETTES}

Table 7 gives the results of the compressive tests of the wallettes. The average results for each kind of mortar show that the cementlime mortar wallettes were 108 per cent stronger, and that the cementmortar wallettes were 182 per cent stronger than those built with lime mortar. 
TABLE 7.-Results of compressive tests of sand-lime brick wallettes

[Thirteen courses about 34 inches high and about 18 inches long]

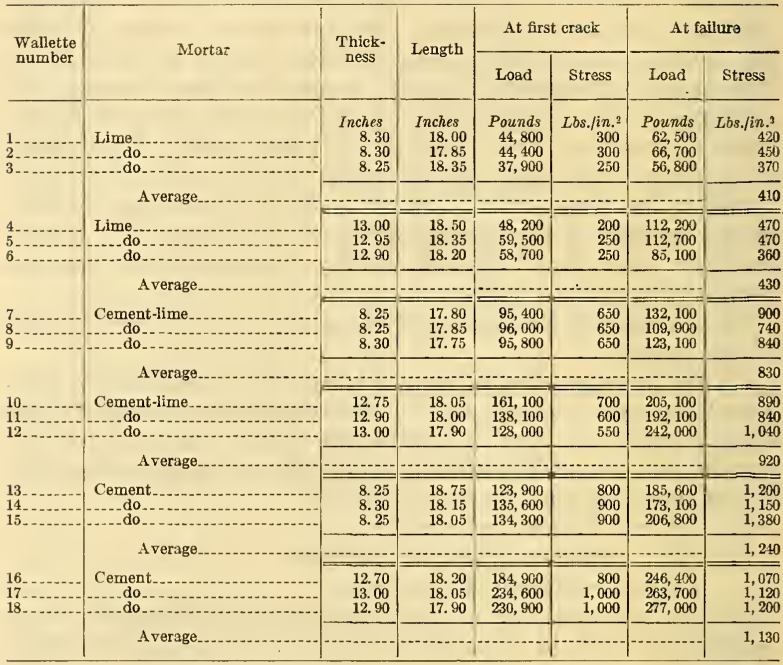

\section{COMPARISON OF WALLS AND WALLETTES}

A comparison of the wall strength to the wallette strength may be found in Table 8 .

TABLE 8.-Comparison of wall strength to wallette strength

\begin{tabular}{|c|c|c|}
\hline $\begin{array}{l}\text { Wall thickness in } \\
\text { inches }\end{array}$ & Mortar & $\begin{array}{l}\text { Ratio of } \\
\text { average wall } \\
\text { strength to } \\
\text { the average } \\
\text { wallette } \\
\text { strength }\end{array}$ \\
\hline $181 / 2$ & $\begin{array}{l}\text { Lime } \\
\text { Cement-lime do } \\
\text { Cement._. }\end{array}$ & $\begin{array}{l}0.77 \\
.67 \\
.82 \\
.61 \\
.77 \\
.75 \\
\end{array}$ \\
\hline & Average & .73 \\
\hline
\end{tabular}

The results show that the walls are from 60 to 80 per cent as strong as wallettes of the size tested. 


\section{CONCLUSIONS}

The results of these compressive tests of 18 walls and 18 wallettes, built of medium grade sand-lime brick in lime, cement-lime and cement mortars, and constructed with ordinary workmanship under average indoor conditions, lead to the following conclusions:

1. The cement-mortar walls were built as rapidly as the limemortar walls and the thickness of the mortar joints was practically the same for all of the walls.

2. For an 8-hour day the rate of laying the brick varied from about 1,200 to 1,400 , depending on the thickness of the wall.

3. The deformation of the walls under a compressive load was not proportional to the load, but could be represented by an equation of the type $S=C d^{\text {n }}$ where $S$ is stress, $C$ is a constant, $d$ is deformation, and the exponent $n$ is less than unity.

4. The stress at failure was greater for the 8-inch walls than for the $12 \frac{1}{2}$-inch walls.

5. The cement-lime mortar walls were 106 per cent stronger and the cement-mortar walls 199 per cent stronger than those built with lime mortar.

6. Based on Masonry Wall Construction, 1923, of the Building Code Committee of the Department of Commerce, the factor of safety for the lime-mortar walls was 2.4, for the cement-lime mortar walls 3.1 , and for the cement-mortar walls 3.6.

7. The ultimate compressive stress of the walls was from 60 to 80 per cent of the ultimate stress of the wallettes.

Washington, August 28, 1924. 